\title{
NUTRITIONAL AND MICROBIOLOGICAL QUALITY OF KUNUN- ZAKI BEVERAGE PRODUCED IN OWERRI MUNCIPAL
}

\author{
Nduka, S.O ${ }^{\mathbf{1}}$, Ezeokeke, T. C. ${ }^{2}$ and Onyeneke, E.N. ${ }^{1}$, \\ Department of Nutrition and Dietetics, Imo State University P.M.B, 2000, Owerri, Nigeria . \\ Department of Biochemistry, Federal University of Technology, Owerri ${ }^{2}$ \\ Corresponding author email: sam4lambert@gmail.com
}

\begin{abstract}
Nutritional and Microbiological qualities of kunu-zaki hawked at different locations in Owerri municipal were assessed and evaluated. Three major locations of production and sales namely: Shell-camp, Ama-Hausa and Obinze all in Owerri municipal were selected for sampling of kunuzaki. Laboratory prepared sample of kunu-zaki was used as control. Samples of kunu were evaluated for microbiological quality such as total bacteria and fungi counts also, biochemical characterization of bacteria and morphological characterization of fungi. Chemical properties which include proximate composition, titrable acidity, $\mathrm{pH}$, total solid and minerals were also examined. Results showed that there was a significant difference $(P<0.05)$ on all the chemical properties of samples examined. The moisture content ranged from $85.14 \%$ to $89.57 \%$ while crude protein was between $2.20 \%$ and $4.09 \%$. Ash content varied significantly $(P>0.05)$ with range $1.67 \%$ to $2.33 \%$. Crude fiber content of $0.71 \%$ of control was higher than $0.68 \%, 0.53 \%$ and $0.44 \%$ found on the hawked kunu-zaki sample. Total carbohydrate was found within ranged values of $5.54 \%$ to $7.74 \%$. Total solid content among kunu-zaki samples ranged from $12.54 \mathrm{mg} / 100 \mathrm{~g}$ to $14.32 \mathrm{mg} / 100 \mathrm{~g}$, pH ranged 5.37 to 5.76 and acidity of the kunu-zaki samples varied but ranged from $0.23 \%$ of sample collected from Obinze location to $0.28 \%$ of Ama-Hausa kunu-zaki sample. Mineral contents of kunu-zaki samples differed significantly $(P<0.05)$, calcium content of $32.09 \mathrm{mg} / 100 \mathrm{~g}$ was higher than $31.21 \mathrm{mg} / 100 \mathrm{~g}, 27.31 \mathrm{mg} 100 \mathrm{~g}$ and $12.53 \mathrm{mg} / 100 \mathrm{~g}$. Potassium content ranged from $311.63 \mathrm{mg} / 100 \mathrm{~g}$ to $449.03 \mathrm{mg} / 100 \mathrm{~g}$. Control laboratory sample was found with highest content of $11.74 \mathrm{mg} / 100 \mathrm{~g}$ magnesium, $4.81 \mathrm{mg} / 100 \mathrm{~g}$ iron and 30.26mg/100g vitamin C. Total bacteria counts of the kunu-zaki samples were not the same; control laboratory sample was least, $3.0 \times 10^{6} \mathrm{cfu} / \mathrm{mL}$ of heterotrophic bacteria, $3.0 \times 10^{6}$ cfu/mL of total Staphylococcus count and $9.0 \times 10^{6} \mathrm{cfu} / \mathrm{mL}$ of fungi counts. Bacteria identified are Bacillus spp, Klebsiella spp, Staphylococcus aureus and Salmonella while fungi suspected include Mucor spp, Saccharomyces spp, Aspergillus spp and Rhizopus. However, laboratory processed samples made kunu-zaki beverage were more acceptable with least microbial load. Good manufacturing and good hygiene practices should be given utmost importance during production to avoid microbial contamination that may cause food borne illness.
\end{abstract}

Keywords: Nutritional, microbiological, Kunun- zaki beverage

Journal of the Faculty of Agriculture and Veterinary Medicine, Imo State University Owerri website: www ajol.info 
https://dx.doi.org/10.4314/jafs.v16i1.5

\section{INTRODUCTION}

Food is any substance, usually composed of carbohydrates, fats, proteins and water, which can be eaten or drank by humans for nutrition or pleasure (A.O.A.C, 2000). In many developing countries like Nigeria, people depend mostly on indigenous technology for food preparations especially food of plant origin, some of these foods that originate from plant include alcoholic beverages made mostly from cereal grains (Adekunle, 2012). Kunu is an important non-alcoholic fermented beverages widely consumed in Northern parts of Nigeria especially during the dry season (Adelekan et al., 2013). Kunu is cheap and the cereals used in its preparation are widely grown throughout the Savanna region of Nigeria such as Bauchi, Kano, Sokoto, and Katsina States (Adeyemi and Umar, 2011). It was consumed primarily (Adepoju et al., 2012) used to be consumed mainly in the Northern parts but it is now widely acceptable in almost all parts of Nigeria, owing to its refreshing qualities. It is acceptable to people of all works of life and is being served at home and public places as food appetizer, refreshing drink and complementary food for infants. The various types of kunu processed and consumed in Nigeria include Kunu zaki, Kunu gyada, Kunu akamu, Kunu tsamiya, Kunu baule, Kunu jiko, Amshau and Kunu gayamba. However, kunu -zaki is the most commonly consumed. Kunu processing is mostly done by women with simple house hold equipment utensil. Depending on cereal availability, sorghum, maize, millet, guinea corn or rice are commonly used for kunu preparation (Alexander and Strette, 2001). Kunu zaki is one of the types of kunu (a non-alcoholic bevereage) that is very popular in the northern part of Nigeria but it is being consumed now in all parts of the country (Adekunle, 2012).

Kunu zaki is produced from millet and sorghum grains. The process of manufacture involves wet milling of millet grains with spices (ginger, clove, black pepper, ehuru) and sweet potato (Ipomea botatas) but sweet potato is optional (Adeyemi and Umar, 2011). The short shelf-life of this beverage is however a major problem faced by their producers and consumers (Adekunle, 2012). Also in developing nations like Nigeria, it has not been possible to have control over the processing of hawked foods, because most of the vendors lack the adequate knowledge of food processing and handling practices. A large number of lactic acid bacteria, coliforms, E. coli, molds and yeast have been reportedly implicated in food spoilage as they use the carbohydrate content of the foods for undesirable fermentation processes (Alexander and Strette, 2001). Research carried out showed that E.coli, Staphylococcus and Salmonella are the major cause of food borne diseases (AOAC, 2000.). The problem of food borne disease or the assessment of the microbiological quality of food cannot be overemphasized, as a result of this; this study will be of an added knowledge to the existing ones. The general objective of this study is to determine the microbiological and nutritionl quality of Kunu beverage produced from different Hausa locations in Owerri, Imo State, Nigeria. 


\section{MATERIALS AND METHODS}

\section{Sample collection}

The kunu samples used in this study were procured from different location in Owerri Municipal Council in Imo State. The locations include Shell camp, Ama-Hausa and Obinze.

\section{Laboratory preparation of Kunu-zaki}

The millet, ginger (dried) and sugar were all purchased from Eke Ukwu market, Owerri, Imo State. The materials were sorted and only those in good condition were used.

\section{Production of Kunu-zaki}

Laboratory sample of Kunu-zaki were produced from 10 grams of millet as shown in Table 3.1. The sample were washed, soaked overnight and wet milled with equal volume of water. Ginger was added to each of the blends prior to milling as indicated in Table 3. 1. Each of the wet milled samples was divided into two equal parts. Two parts were prepared into a thick porridge using boiled water. The remaining one part of the wet milled samples were added back to their respective thick porridges and stirred. They were allowed to stand overnight for about 15 hours to allow for fermentation and flavour development. The fermented samples were sieved using muslin cloth to give the different kunu-zaki samples which were used for subsequent analysis.

\section{Proximate Composition Analysis}

This was carried out according to the method of(AOAC, 2000)

\section{Moisture Content Determination}

Two grams of each of the sample was weighed into dried weighed crucible. The samples was put into a moisture extraction oven at $105^{\circ} \mathrm{C}$ and heated for $3 \mathrm{~h}$. The dried samples was put into desiccators, allowed to cool and reweighed. The process was reported until constant weight was obtained. The difference in weight was calculated as a percentage of the original sample Percentage moisture

Where

$$
=\frac{\mathrm{W} 2-\mathrm{W} 1 \times 100}{\mathrm{~W} 2-\mathrm{W} 31}
$$

W1 = Initial weight of empty dish, W2 = Weight of dish + undried sample, W3 = Weight of dish + dried sample 


\title{
Ash Content Determination
}

Two grams of each of the samples was weight into crucible, heated in a moisture extraction oven for $3 \mathrm{~h}$ at $100^{\circ} \mathrm{C}$ before being transferred into a muffle furnace at $550^{\circ} \mathrm{C}$ until it turned white and free of carbon. The sample was then removed from the furnace, cooled in a desiccator to a room temperature and reweighed immediately. The weight of the residual ash was then calculated as Ash Content

Percentage Ash $=\frac{\text { Weight of Ash }}{\text { Weight of original of smaple }} \times \frac{100}{1}$

\section{Crude Protein Determination}

The micro kjeldahl method described by (AOAC, 2000) was used. Two grams of each of the samples wasmixed with $10 \mathrm{ml}$ of concentrated $\mathrm{H}_{2} \mathrm{SO}_{4}$ in a heatingtube. One table of selenium catalyst was added to thetube and mixture heated inside a fume cupboard. Thedigest was transferred into distilled water. Tenmillimeter portion of the digest mixed with equalvolume of $45 \% \mathrm{NaOH}$ solution and poured into akjeldahl distillation apparatus. The mixture was distilledand the distillate collected into $4 \%$ boric acid solutioncontaining 3 drops of methyl red indicator. A total of $50 \mathrm{ml}$ distillate was collected and titrated as well. The sample was duplicated and the average value taken. TheNitrogen content was calculated and multiplied with6.25 to obtain the crude protein content.This is given as percentage Nitrogen

\author{
$=\frac{(100 \times \mathrm{N} \times 14 \times \mathrm{VF}) \mathrm{T}}{100 \times \mathrm{Va}}$ \\ Where, \\ $\mathrm{N}=$ Normality of the titrate $(0.1 \mathrm{~N})$ \\ $\mathrm{VF}=$ Total volume of the digest $=100 \mathrm{ml}$ \\ $\mathrm{T}=$ Titre Value \\ $\mathrm{Va}=$ Aliquot Volume distilled
}

\section{Fat content determination}

Two grams of the sample was loosely wrappedwith a filter paper and put into the thimble which wasfitted to a clean round bottom flask, which has beencleaned, dried and weighed. The flask contained $120 \mathrm{mlof}$ petroleum ether. The sample was heated with aheating mantle and allowed to reflux for $5 \mathrm{~h}$. The heatingwas then stopped and the thimbles with the spent samples kept and later weighed. The difference in weight was received as mass of fat and is expressed in percentage of the sample.

The percentage oil is percentage fat $=\frac{\mathrm{w} 2-\mathrm{w} 1}{\mathrm{w} 3} \times \frac{100}{1}$

\section{Where,}

$\mathrm{W} 1=$ weight of the empty extraction flask

$\mathrm{W} 2$ = weight of the flask and oil extracted

$\mathrm{W} 3=$ weight of the sample

Journal of the Faculty of Agriculture and Veterinary Medicine, Imo State University Owerri website: www ajol.info 


\section{Crude fibre determination}

Two grams (2g) sample and $1 \mathrm{~g}$ asbestos were put into $200 \mathrm{ml}$ of $1.25 \%$ of $\mathrm{H} 2 \mathrm{~S} 04$ and boiled for 30 minutes. The solution and content then poured into Buchner funnel equipped with muslin cloth and secured with elastic band. This was allowed to filter and residue was then put into $200 \mathrm{ml}$ boiled $\mathrm{NaOH}$ and boiling continued for 30 minutes, then transferred to the buchner funnel and filtered. It was then washed twice with alcohol, the material obtained washed thrice with petroleum ether. The residue obtained was put in a clean dry crucible and dried in the moisture extraction oven to a constant weight. The dried crucible was removed, cooled and weighed. Then, difference of weight (i.e. loss in ignition) is recorded as crucible fibre and expressed in percentage crude fibre

$=\frac{W 1-W 2}{W 3} \times \frac{100}{1}$

Where,

$\mathrm{W} 1$ = weight of sample before incineration

$\mathrm{W} 2$ = weight of sample after incineration

$\mathrm{Wt}=$ weight of original sample

\section{Carbohydrate content determination}

The nitrogen free method described by (AOAC, 2000) was used. The carbohydrate is calculated as weight by difference between 100 and the summation of other proximate parameters as Nitrogen free Extract (NFE) percentage carbohydrate

$(\mathrm{NFE})=100-\left(\mathrm{m}+\mathrm{p}+\mathrm{F}_{1}+\mathrm{A}+\mathrm{F}_{2}\right)$

Where

$\mathrm{m}=$ moisture

$\mathrm{p}=$ protein

$\mathrm{F}_{1}=$ Fat

$\mathrm{A}=$ ash

$\mathrm{F}_{2}=$ Crude fibre

\section{Determination of mineral composition of samples}

The methods of (Chowdhurys and Punia, 2007) were used for the determination of minerals (Ca, $\mathrm{Mg}, \mathrm{K}, \mathrm{Na}, \mathrm{P}$ and $\mathrm{Fe}$ ) by atomic absorption spectrophotometer. One gram samples, in triplicate were dry, ashed in a muffle furnace at $550^{\circ} \mathrm{C}$ for $8 \mathrm{~h}$ until a white residue of constant weight were obtained. The minerals were extracted from ash by adding $20.0 \mathrm{~mL}$ of $2.5 \% \mathrm{HCl}$, and this was transferred quantitatively to a $50 \mathrm{~mL}$ volumetric flask. It was diluted to volume $(50 \mathrm{~mL})$ with 
deionised water, stored in clean polyethylene bottles and mineral contents determined using an atomic absorption spectrophotometer (Perkin- Elmer, Model 2380, USA)

\section{Determination of microbial population}

Microbial count was done according to ICMSF (Jango-Cohen, 2005). Ten grams (10gmL) of each sample was serially diluted into 10- folds dilution using sterile peptone water, and then homogenized by shaking vigorously. An aliquot portion $(0.1 \mathrm{ml})$ of $3^{\text {rd }}$ up to $5^{\text {th }}$ dilution was inoculated in duplicate onto the potato dextrose agar (PDA), and nutrient agar (NA) (MA) for the isolation of heterotrophic fungi and bacteria respectively. Potato dextrose agar plates were incubated at ambient temperature $\left(28^{\circ}+02^{\circ} \mathrm{C}\right)$ for fungal growth. The nutrient agar plates was spread evenly with a sterile spreader and incubated for $24-48 \mathrm{~h}$ at different temperatures $37^{\circ} \mathrm{C}$ for total viable count (Alexander and Strette, 2001).

\section{Biochemical reaction of microbes}

Species that cannot be distinguished by their cultural microscopic characteristics may exhibit distinct difference in their biochemical reactions is provided by (Alexander and Strette, 2001).

\section{Carbohydrates Fermentation Test}

The ability of organisms to ferment sugars could be used as a distinguish factor. An liquot portion of the basal medium (peptone sugar water) was dispersed into a test-tube and filled by gently inversion with the medium. The cultures (twenty-four hours old) was inoculated into the sterilized medium and incubated for forty eighth hours at $37^{\circ} \mathrm{C}$. A color change from red to yellow (with phenol red indicator) and air space in the Durham tubes was considered positive, indicating acid and gas production respectively.

\section{Catalase Test}

Aerobic and aero-tolerant organisms have the ability to produce an enzyme-catalase that splits $\mathrm{H}_{2} \mathrm{O}_{2}$, a toxic compound produced in the respiratory process to oxygen and water. To test for the presence of catalase, a loop full of test culture (twenty four hours old) was placed on a clean, grease free slide. Add a loopful of the $\mathrm{H}_{2} \mathrm{O}_{2}$ and mix thoroughly with the edge of a slide. Effervescence due to the liberation of oxygen indicates a positive catalase reaction.

\section{Coagulase Test}

This test differentiates Staphylococcus aureus which produce the enzyme coagulase from the non-coagulase producing staphylococcus and microcossus species. The enzyme coagulates causes plasma to clot by converting fibrinogen to fibrin. Place a drop of physiological saline on each end of a slide. Emulsify a colony of the test organism on each of the drop to make two thick suspensions. Add a drop of plasma to one of the suspension and mix gently. Look for clumping of the organism within ten seconds. 


\section{Oxidase Test}

Some organisms have the tendency of forming a complex mixture with the oxidase reagent (para-amino dimethyl phenylenedimine monochloride and water) and appearing purple on filter paper soaked with the reagent.

\section{Procedure}

Few drops of freshly prepared oxidase reagent will be placed on sterile filter paper. Test cultures (Twenty four hours old) were streaked on the filter paper soaked with the reagent. The appearance of a purple color after ten seconds indicates positive reaction.

\section{Imvic Test}

This test consists of four different tests; they are Indole production, Methyl-red test, Voges Proskauer tests and the physiological properties of microorganisms. They are especially useful in the differentiation of Gram negative intestinal bacilli, particularly Escherichia coli and the Enterobacter-klebsiella group.

Indole Production: Indole is produced in triptone broth by the enzyme of certain organisms. Triptone broth is rich in amino acid tryptophan which can be used by some bacteria as source of carbon, energy as well as nitrogen. Tryptophan is degraded to indole pyruvic acid and ammonia by some microorganisms. A loopful of test culture (Twenty four hour old) was inoculated into the triptone broth and incubated for two days. Into six milliliters of culture broth a three milliliters of Kovac's reagent was added from aqueous layer, colour change to red is a positive test.

Methylred and Voges-Proskaeur tests must be considered together from the MR and VP test, i.e. MR +, VP- or MR-, VP+. Methyl red test was performed to demonstrate the capacity of different organisms to produce acid from the fermentation of sugar (dextrose). Methyl red positive organisms produce a red coloration when five drops of methyl red-indicator is added into forty-eight hour old MR-VP culture. The Voges-Proskuer test demonstrates the ability of organisms to produce acetone from glucose metabolism. Some organisms metabolize glucose to produce pyruvic acid which is further broken down to yield butane-diol and acetyl-methyl carbonyl as an intermediate product. Into one milliliter of the culture add one milliliter of six percent alcoholic solution of alpha-naphthol ( $\propto$-naphthiol) and one milliliter of $16 \% \mathrm{Kott}$ and stand for 15-20 minutes. Development of red to pink colour is a positive test.

\section{Citrate Test}

The citrate test was performed by inoculating into organic synthetic medium in which sodium citrate is the only sources of carbon and energy. In sodium citrate broth (Koser's citrate medium), the presence of growth (turbidity) is a positive test result. 


\section{Motility Test}

The ability of an organism to move is determined by the presence of one or more flagella. In the laboratory, motility test of micro organisms, especially bacteria is demonstrated by the hanging drop method. A loopful of broth culture of the test organism was dropped at the centre of Vaseline made into a cycle on clean grass free microscopic slide. A cover slip is placed on top of the Vaseline and inverted. Motility was observed with the low magnifications $\left(10^{x}\right.$ and $\left.40^{x}\right)$. The appearance of darting or rigging in the broth signifies motility. (Jango-Cohen, 2005), (Alexander, and Strette, 2001), Buchannan consulted in the identification of the organisms taking into consideration the test performed.

\section{Statistical analysis}

Data were subjected to Analysis of Variance (ANOVA version 20.0) and Turkey's test was used for comparison of means.

\section{RESULTS}

The proximate composition of kunu zaki sample is shown in Table 4.1. The proximate composition showed significant difference $(\mathrm{p}<0.05)$ among the samples. The moisture content ranged from $85.14-89.57 \%$. The kunu sample from shell camp has the highest moisture content of $89.57 \%$, followed by kunu sample from Obinze and Ama-hausa with $88.35 \%$ and $87.69 \%$ respectively while control sample has the least value of $85.14 \%$. The protein content varies significantly from $2.20-4.09 \%$. The control sample has the highest protein value of $4.09 \%$ followed by kunu sample from Ama-Hausa and Obinze with $3.77 \%$ and $2.84 \%$ while kunu sample from Shell camp has the least value of $2.20 \%$. The Ash content ranged between $1.67 \%$ and $2.33 \%$. The sample control has the highest value of $2.33 \%$ while kunu sample from AmaHausa has the least value of $1.67 \%$. The crude fiber content varies from $0.44-0.71 \%$. The control sample has the highest crude fiber value of $0.71 \%$ followed by kunu sample from Shell camp and Obinze with $0.68 \%$ and $0.53 \%$ while kunu sample from Ama-Hausa has the least value of $0.44 \%$. The carbohydrate content varies between $5.54-7.74 \%$. The control sample has the highest value of $7.74 \%$ while kunu sample from shell camp has the least value of $5.54 \%$.

The chemical properties of Kunu zaki is presented in Table 4.2. The Total solid content of the samples was not the same. Total solid of $14.32 \mathrm{mg} / 100 \mathrm{~g}$ of the control kunu samples was higher than $13.46 \mathrm{mg} / 100 \mathrm{~g}$ of Ama-Hausa, $13.02 \mathrm{mg} / 100 \mathrm{~g}$ of Obinze and the least $12.54 \mathrm{mg} / 100 \mathrm{~g}$ was found on sample collected from Shell-camp. The $\mathrm{pH}$ varies from 5.37 -5.76. the kunu sample from Obinze has the highest $\mathrm{pH}$ value of 5.76 while the kunu sample from Ama-Hausa sample has the least value of 5.37. The Acidity ranged from $0.23-0.28 \mathrm{mg} / 100$. The kunu sample from Ama-Hausa has the highest acidity value of $0.28 \mathrm{mg} / 100 \mathrm{~g}$ while kunu sample from Obinze has the least value $0.23 \mathrm{mg} / 100 \mathrm{~g}$.

Journal of the Faculty of Agriculture and Veterinary Medicine, Imo State University Owerri website: www ajol.info 
The mineral and Vitamin $\mathrm{C}$ composition of kunu zaki is presented in table 4.3. The calcium content varies from $12.53-32.09 \mathrm{mg} / 100 \mathrm{~g}$. The control sample has the highest calcium value of $32.09 \mathrm{mg} / 100 \mathrm{~g}$ while the kunu sample from Obinze has the least value of $12.53 \mathrm{mg} / 100 \mathrm{~g}$. The potassium content ranged between $311.63-449.03 \mathrm{mg} / 100 \mathrm{~g}$. The control sample has the highest potassium value of $449.03 \mathrm{mg} / 100 \mathrm{~g}$ followed by kunu sample from Obinze and Shell camp with $412.03 \mathrm{mg} / 100 \mathrm{~g}$ and $399.08 \mathrm{mg} / 100 \mathrm{~g}$ while kunu sample from Ama-Hausa has the least value Of $311.63 \mathrm{mg} / 100 \mathrm{~g}$. The magnesium content varies significantly from $5.44-11.74 \mathrm{mg} / 100 \mathrm{~g}$. The control sample has the highest magnesium value of $11.74 \mathrm{mg} / 100 \mathrm{~g}$ while kunu sample from Ama-Hausa has the least value of $5.44 \mathrm{mg} / 100 \mathrm{~g}$. The control sample has the highest value of iron and vitamin $C$ with $4.81 \mathrm{mg} / 100 \mathrm{~g}$ and $30.26 \mathrm{mg} / 100 \mathrm{~g}$ respectively while kunu sample from AmaHausa has the least value of iron and vitamin $C$ with $1.19 \mathrm{mg} / 100 \mathrm{~g}$ and $22.14 \mathrm{mg} / 100 \mathrm{~g}$ respectively.

\section{DISCUSSION}

\section{Proximate composition}

The proximate composition of kunu zaki sample is shown in Table 4.1. The proximate composition showed significant difference $(\mathrm{p}<0.05)$ except the crude fiber that show no significant difference $(\mathrm{p}>0.05)$ among the samples. The moisture content ranged from 85.14$89.57 \%$.The moisture content of the kunu zaki is high. High moisture content in food influence protection against micro-organism which affect the stability and safety of food, hence refrigeration or freeze would be required to extend the shelf life of the product. The high moisture content found on the samples suggests that they can be used as refreshing drink that quenches thirst. This is typical of refreshing drinks. The moisture content of the beverages was however in line with the one as reported for juice from Spondiasmombin and extract of Hibiscussabdariffa (Adepoju and Oladejo, 2012). Water is the most important constituent of every living cell. It takes part in various chemical and biochemical processes including hydrolytic breakdown of nutrients during digestion, is continually lost from the body through urine, stools, sweat, and is expelled through respiration. Water imbalance leads to serious conditions such as dehydration which may be fatal (Pelczar et al., 1993). The protein content varies significantly from $2.20-4.09 \%$.there is significant difference $(\mathrm{p}<0.05)$ among the kunu samples examined. The protein content of the samples in this work was higher than the value reported by (Chowdhurys, and Punia, 2007), and this may be attributed to the raw material adopted during the production of beverages. The improved protein content of kunu-zaki recorded in this study may be beneficial to consumers of the products as majority of people in Nigeria could not afford protein sources of food such as meat and egg for economic reasons. The ash content ranged between $1.67 \%$ and $2.33 \%$. (Iwe, 2002) reported that ash content of food is a measure of mineral element present in food stuff. (Adelekan et al., 2013) reported increase in the 
ash content of kunun-zaki enriched with extract of sesame seeds over the control sample. Values of the ash contents in the knun-zaki recorded by the research workers are similar to those obtained in the present study. However, (Iwe, 2002) and (Adelekan et al., 2013) obtained ash content of higher values in their finding on kunu-zaki than those recorded in this study. The difference could be attributed to the types of cereals or raw materials used in the production of the beverage in the different studies. Different cereal types have abilities to contribute to the ash content of kunu- zaki as a result of the differences in their ash compositions. The crude fiber of the samples showed significant difference $(\mathrm{p}<0.05)$ with statistical analysis. This could be as a result of higher content of fiber contained in the raw materials used. The carbohydrate content of the sample showed significant difference $(\mathrm{p}<0.05)$. The high carbohydrate content of kunun-zaki indicates a good source of energy needed for human activity (Iwe, 2002).

\section{Chemical properties of Kunu zaki}

The chemical properties of kunu zaki are presented in Table 4.2. All the samples were slightly acidic with $\mathrm{pH}$ range of 5.37 to 5.76 . This could be attributed to lactic acid fermentation of the beverage which led to the production of lactic acids which caused slight acidity of the samples (Adebayo et al., 2010). The low value of TTA for samples indicates poor fermentation which could have caused poor production of lactic acid. This invariably led to higher $\mathrm{pH}$ value of this sample when compared with the other samples.

\section{Mineral and Vitamin C Composition of Kunu zaki}

Table 4.3 showed the mineral and vitamin $\mathrm{C}$ composition of Kunun zaki samples. The calcium content varies from $12.53 \mathrm{mg} / 100 \mathrm{~g}$ to $32.09 \mathrm{mg} / 100 \mathrm{~g}$. Calcium helps in the regulation of muscle contractions and transmission of nerve impulses as well as bone and teeth development (Adelekan et al.,2013). The potassium content ranged between $311.63 \mathrm{mg} / 100 \mathrm{~g}$ and $449.03 \mathrm{mg} / 100 \mathrm{~g}$. Potassium is essential for its important role is the synthesis of amino acids and protein. The increases in the content of the minerals recorded in the Kunu-Zaki sample could therefore be of nutritional advantage to consumers of the products. There is significant difference $(\mathrm{p}<0.05)$ on the magnesium, iron and zinc content among the sample examined..The increase in the mineral content in the samples could therefore justify the need to enrich the beverage with source that are rich in other nutrients lacking in cereals normally adopted in its production (Chowdhurys, and Punia, 2007). Minerals are of great importance in diet as they play important roles in body metabolism.

\section{Microbiological quality of Kunu zaki}

The microbes found associated with both the hawked and the laboratory prepared kunun sample comprises of bacteria which includes, Bacillus sutilis, Staphylococcus aureus, Klebsiella sp, and Salmonella sp the mould which are, Apergillus niger, Rhizopus spp and Mucor spp andthe yeast Journal of the Faculty of Agriculture and Veterinary Medicine, Imo State University Owerri website: www ajol.info 
which includes and Saccharomyces cerevisiae. The presence of some of these organisms are not surprising as most of them are known to thrive in medium rich in fermentable substrates such as sugars which often led to the production of acids after fermentation. The presence and the activities of these fermenters might be responsible for the souring of taste usually observed if not consumed within six hours of processing (Odunfa. and Adeyeye, 2005.) found that Bacillus and Lactobacillus species were readily found in foods of low acid content like juices and beverages where they produce organic acids. Bacillus species are spore formers whose spores could survive high temperatures of processing. The thermoduric nature of the spores of these microbes ensures survival at pasteurization temperatures and hence their presence in the kunun samples that have been subjected to heat treatment during processing. Some of these associated microbes have been implicated in food poisoning out breath of some food materials (Amusa and. Odunbaku, 2009). However, (Adebayo, et al., 2010) reported that staphylococcus spp level of $10^{8} \mathrm{ml}^{-1}$ is considered potential hazardous to consumers. These fungi also have high survival rate of their spores hence their presence in these food drinks could have emanated from the air as air since most of the hawked hkunu drinks are not usually well covered. The presence of coliform bacterial in the hawked kunu drinks in Nigeria is a source of concern because the teaming populace relies on these drinks as alternative to the bottled soft drinks whose price is becoming unaffordable.

\section{CONCLUSION}

The results obtained from the different analyses of the Kunu-zaki beverages showed that the laboratory processed sampled did not alter the proximate, chemical and mineral properties of the beverage rather it helped to improve these properties thereby making them more acceptable. However, microbial content of these hawked marketed Kunu-zaki drinks was higher and showed high microbial load which may be potential pathogens to consumers.

\section{RECOMMENDATION}

Good manufacturing and good hygiene practices should be given utmost importance during production to avoid microbial contamination that may cause food borne illness. 


\section{REFERENCES}

Adebayo, G. B., G. A. Otunola and T. A. Ajao (2010) Physicochemical, microbiological and sensory characteristics of kunu prepared from millet, maize and guinea corn and stored at selected temperature. Advanced Journal of Food Science and Technology, 2(1): 41 - 46.

Adekunle, A.A (2012). Agricultural innovation in Sub-Saharan Africa: Experiences from multiple State holder Approaches Forum for Agriculture Research in Africa, Ghana. ISBN 978-9988-8373-2-4.

Adelekan A. O., Alamu A. E., Arisa N. U., Adebayo Y. O., and Dosa A. S.. (2013). Nutritional, microbiological and sensory characteristics of malted soy-kunu zaki: an improved traditional beverage. Advances in Microbiology,3:389-397.

Adepoju, Oladejo and Thomas (2012). Effects of processing methods on nutrient retention and contribution of white yam (Dioscorea rotundata) products to nutritional intake of Nigerians. African Journal of Food Science, 6(6):163-167.

Alexander, S.K. and D. Strette (2001). Microbiology a photographic after for the laboratory. Benjamin curnmings, San Francisco CA.

Adeyemi, I.A., and S. Umar, 2011. Effect of method of manufacture on the quantity characteristics of Kunu-zaki a millet based beverage. Nigeria food Journal, 12: 34-40.

Amusa, N.A. and O.A. Odunbaku,( 2009). Microbiological and Nutritional quality of hawked Kunu (A sorghum based non-alcoholic beverage) widely consumed in Nigeria. Journal of Nutrition, 8(1): 20-25.

AOAC (2000).Official Methods of Analysis, 17th edn. Association of Official Analytical Chemists.Washington D.C.

Chowdhurys, Punia D. (2007), Nutrient and Anti-nutrient Composition of Pearl Millet Grains as Affected by Milling and Baking. Nahrun, 41(2): 105-107.

Iwe, M. O. (2002). Handbook of Sensory Methods and Analysis.Rejoint Communication Services Ltd Uwani Enugu. Pp 40 - 83.

Jango-Cohen, J., (2005). History of Food. London: Twenty-First Century Book Publishers, PP:48.

Pelczar M. J., Chane C. S., and Noel R. K.. (1993). Microbiology. 5th ed. McGraw-Hill Publishing Company, New Delhi: p. 272.

Odunfa, S.A. and S. Adeyeye, 2005. "Microbiological Changes during the traditional production of Ogidaba, a West African fermented sorghum gruel. Journal of Cereal Science, 3:173180 . 


\section{APPENDIX}

\section{Millet}

Sorting, Cleaning and washing

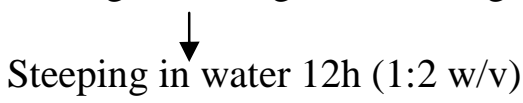

Decanting and washing

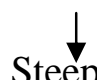

Steep in water

Rinse in water

Wet milling (Sterilized blender)

Slurry divided into two
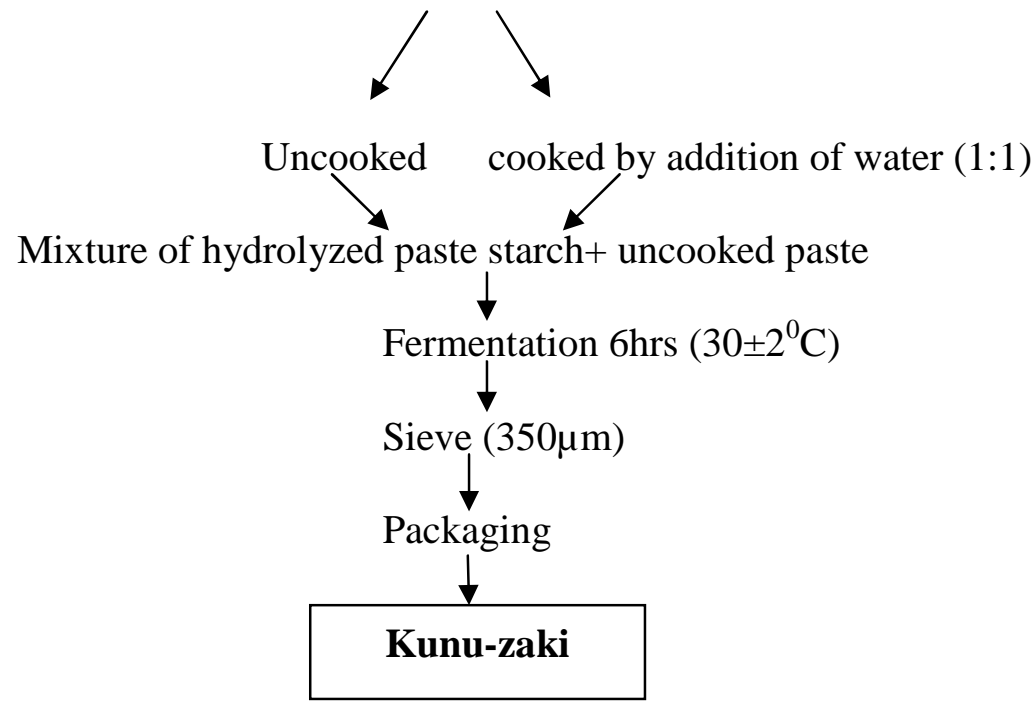

Figure 1: Chart for Kunu-zaki production using millet

Journal of the Faculty of Agriculture and Veterinary Medicine, Imo State University Owerri website: www ajol.info 
Proximate composition of Kunun-zaki from Owerri Municipal

Table 1: Proximate composition of kunu zaki

\begin{tabular}{llllll}
\hline Sample & $\begin{array}{l}\text { Moisture } \\
\mathbf{\%}\end{array}$ & $\begin{array}{l}\text { Protein } \\
\mathbf{\%}\end{array}$ & $\begin{array}{l}\text { Ash } \\
\mathbf{\%}\end{array}$ & $\begin{array}{l}\text { Crude fiber } \\
\text { \% }\end{array}$ & $\begin{array}{l}\text { Carbohydrate } \\
\text { \% }\end{array}$ \\
\hline $\begin{array}{l}\text { Shellcamp kunun } \\
\text { sample }\end{array}$ & $89.57^{\mathrm{a}} \pm 0.02$ & $2.20^{\mathrm{d}} \pm 0.03$ & $2.02^{\mathrm{b}} \pm 0.03$ & $0.68^{\mathrm{a}} \pm 0.02$ & $5.54^{\mathrm{d}} \pm 0.09$ \\
$\begin{array}{l}\text { Ama-hausa kunun } \\
\text { sample }\end{array}$ & $87.69^{\mathrm{c}} \pm 0.03$ & $3.77^{\mathrm{b}} \pm 0.02$ & $1.67^{\mathrm{c}} \pm 0.03$ & $0.44^{\mathrm{c}} \pm 0.02$ & $6.44^{\mathrm{b}} \pm 0.06$ \\
$\begin{array}{l}\text { Obinze kunun sample } \\
\text { Laboratory control }\end{array}$ & $88.35^{\mathrm{b}} \pm 0.03$ & $2.84^{\mathrm{c}} \pm 0.03$ & $2.09^{\mathrm{b}} \pm 0.01$ & $0.53^{\mathrm{b}} \pm 0.0$ & $6.19^{\mathrm{c}} \pm 0.01$ \\
kunun sample & $85.14^{\mathrm{d}} \pm 0.03$ & $4.09^{\mathrm{a}} \pm 0.04$ & $2.33^{\mathrm{a}} \pm 0.03$ & $0.71^{\mathrm{a}} \pm 0.01$ & $7.74^{\mathrm{a}} \pm 0.03$ \\
LSD & 0.027 & 0.029 & 0.025 & 0.015 & 0.059 \\
\hline
\end{tabular}

Mean values with the different letters are significant $(\mathrm{p}<0.05)$ in the same column, LSD-=L east significant difference.

Total solid, pH and acidity content of Kunun-zaki from Owerri Municipal

Table 2: Chemical properties of Kunu zaki

\begin{tabular}{llll}
\hline Sample & $\begin{array}{l}\text { Total solid } \\
\mathbf{m g} / \mathbf{1 0 0 g}\end{array}$ & $\mathbf{p H}$ & $\begin{array}{l}\text { Acidity } \\
\text { \% }\end{array}$ \\
\hline $\begin{array}{l}\text { Shellcamp kunun sample } \\
\text { Ama-Hausa kunun sample }\end{array}$ & $12.54^{\mathrm{d}} \pm 0.01$ & $5.49^{\mathrm{c}} \pm 0.01$ & $0.26^{\mathrm{b}} \pm 0.01$ \\
$\begin{array}{l}\text { Obinze kunun sample } \\
\text { Laboratory control kunun }\end{array}$ & $13.46^{\mathrm{b}} \pm 0.01$ & $5.37^{\mathrm{d}} \pm 0.01$ & $0.28^{\mathrm{a}} \pm 0.01$ \\
$\begin{array}{l}\text { sample } \\
\text { LSD }\end{array}$ & $14.32^{\mathrm{a}} \pm 0.01$ & $5.76^{\mathrm{a}} \pm 0.01$ & $0.23^{\mathrm{c}} \pm 0.02$ \\
\hline
\end{tabular}

Mean values with the different letters are significant $(p<0.05)$ in the same column, LSD-=Least significant difference. 
Minerals content of Kunun-zaki from Owerri Municipal

Table 3: Mean values of mineral composition of kunu zaki

\begin{tabular}{lccccc}
\hline Sample & $\begin{array}{c}\text { Calcium } \\
\mathbf{m g} / \mathbf{1 0 0 g}\end{array}$ & $\begin{array}{c}\text { Potassium } \\
\mathbf{m g} / \mathbf{1 0 0 g}\end{array}$ & $\begin{array}{c}\text { Magnesium } \\
\mathbf{m g} / \mathbf{1 0 0 g}\end{array}$ & $\begin{array}{l}\text { Iron } \\
\mathbf{m g} / \mathbf{1 0 0 g}\end{array}$ & $\begin{array}{l}\text { Vitamin C } \\
\mathbf{~ m g / 1 0 0 g}\end{array}$ \\
\hline $\begin{array}{l}\text { Shellcamp kunun } \\
\text { sample }\end{array}$ & $12.53^{\mathrm{a}} \pm 17.72$ & $399.08^{\mathrm{c}} \pm 0.06$ & $6.89^{\mathrm{c}} \pm 0.01$ & $2.22^{\mathrm{c}} \pm 0.01$ & $26.59^{\mathrm{c}} \pm 0.01$ \\
$\begin{array}{l}\text { Ama-hausa kunun } \\
\text { sample }\end{array}$ & $31.21^{\mathrm{a}} \pm 0.01$ & $311.63^{\mathrm{d}} \pm 0.04$ & $5.44^{\mathrm{d}} \pm 0.02$ & $1.19^{\mathrm{d}} \pm 0.02$ & $22.14^{\mathrm{d}} \pm 0.02$ \\
$\begin{array}{l}\text { Obinze kunun } \\
\text { sample }\end{array}$ & $27.31^{\mathrm{a}} \pm 0.04$ & $412.03^{\mathrm{b}} \pm 0.04$ & $8.09^{\mathrm{b}} \pm 0.04$ & $2.76^{\mathrm{b}} \pm 0.01$ & $27.32^{\mathrm{b}} \pm 0.02$ \\
$\begin{array}{l}\text { Laboratory control } \\
\text { kunun sample }\end{array}$ & $32.09^{\mathrm{a}} \pm 0.04$ & $449.03^{\mathrm{a}} \pm 0.04$ & $11.74^{\mathrm{a}} \pm 0.05$ & $4.81^{\mathrm{a}} \pm 0.01$ & $30.26^{\mathrm{a}} \pm 0.03$ \\
\begin{tabular}{l} 
LSD \\
\hline
\end{tabular} & 8.860 & 0.045 & 0.032 & 0.015 & 0.022 \\
\hline
\end{tabular}

Mean values with the different letters are significant $(\mathrm{p}<0.05)$ in the same column, $\mathrm{LSD}=$ Least significant difference.

Microbiological quality of Kunun-zaki from Owerri Municipal

Table 4: Microbial Counts $c f u / m L$ of the samples Analyzed

\begin{tabular}{llllll}
\hline Samples/count & THBC & TCC & TSSC & TSC & TFC \\
\hline Shellcamp kunun sample & $5.5 \times 10^{7}$ & $5.2 \times 10^{5}$ & 0 & $6.0 \times 10^{5}$ & $3.0 \times 10^{5}$ \\
Ama-hausa kunun sample & $5.2 \times 10^{6}$ & $8.0 \times 10^{4}$ & 0 & $4.7 \times 10^{5}$ & $2.1 \times 10^{5}$ \\
Obinze kunun sample & $8.0 \times 10^{6}$ & $3.2 \times 10^{6}$ & $3.0 \times 10^{4}$ & $3.2 \times 10^{5}$ & $4.0 \times 10^{5}$ \\
$\begin{array}{l}\text { Laboratory control kunun } \\
\text { sample }\end{array}$ & $3.0 \times 10^{6}$ & 0 & 0 & $3.0 \times 10^{6}$ & $9.0 \times 10^{4}$ \\
\end{tabular}

Key

$\mathrm{THBC}=$ Total heterotrophic bacteria count

$\mathrm{TCC}=$ Total coliform count

$\mathrm{TSSC}=$ Total salmonella/shigella count

$\mathrm{TSC}=$ Total staphylococcus count

$\mathrm{TFC}=$ Total fungi count 
Table 5: Biochemical identification of pure culture of bacteria isolate

\begin{tabular}{|c|c|c|c|c|c|c|c|c|c|}
\hline ن & 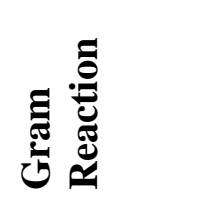 & 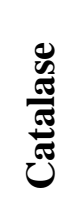 & נֶ & 帝 & $\frac{\stackrel{\varrho}{\varrho}}{\varrho}$ & 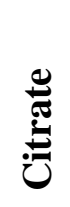 & $\sum_{\sum}^{\bar{e}}$ & 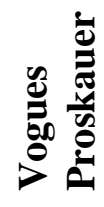 & 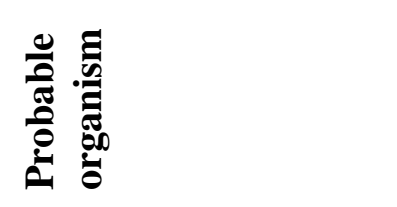 \\
\hline 1 & +ve Rod & + & - & + & - & + & - & + & Bacillus sp \\
\hline A2 & -ve Rod & + & - & - & - & + & - & + & Klebsiella sp \\
\hline A3 & +ve Cocci & + & + & - & - & + & - & + & Staphylococcus aureus \\
\hline B1 & +ve Rod & + & - & + & - & + & - & + & Bacillus sp \\
\hline B2 & -ve Rod & + & - & - & - & + & - & + & Klebsiella sp \\
\hline B3 & +ve Cocci & + & + & - & - & + & - & + & Staphylococcus aureus \\
\hline $\mathrm{C} 1$ & +ve Rod & + & - & + & - & + & - & + & Bacillus $s p$ \\
\hline $\mathrm{C} 2$ & -ve Rod & + & - & - & - & + & - & + & Klebsiella $s p$ \\
\hline $\mathrm{C} 3$ & +ve Cocci & + & + & - & - & + & - & + & Staphylococcus aureus \\
\hline $\mathrm{C} 4$ & -ve Rod & + & - & + & - & + & + & - & Salmonella $s p$ \\
\hline D1 & +ve Rod & + & - & + & - & + & - & + & Bacillus sp \\
\hline D2 & +ve Cocci & + & + & - & - & + & - & + & Staphycoccus aureus \\
\hline
\end{tabular}

Journal of the Faculty of Agriculture and Veterinary Medicine, Imo State University Owerri website: www ajol.info 